\title{
Stunted Patches in Onion Bulb Crops in Oregon and Washington: Etiology and Yield Loss
}

Dipak Sharma-Poudyal, Postdoctoral Research Associate, Washington State University, Pullman 99164; Timothy C. Paulitz, Plant Pathologist, USDA ARS, Pullman, WA 99164; and Lindsey J. du Toit, Professor, Washington State University Mount Vernon NWREC, Mount Vernon 98273

\begin{abstract}
Sharma-Poudyal, D., Paulitz, T. C., and du Toit, L. J. 2015. Stunted patches in onion bulb crops in Oregon and Washington: Etiology and yield loss. Plant Dis. 99:648-658.

Onion stunting caused by Rhizoctonia spp. is an important soilborne disease on very sandy soils in the Columbia Basin of Oregon and Washington. From 2010 to 2013, 251 isolates of Rhizoctonia or Rhizoctonia-like spp. were obtained from soil and onion plant samples collected from inside and outside patches of stunted plants in 29 onion fields in the Columbia Basin. Sequence analysis of the internal transcribed spacer (ITS) region was used to identify the isolates, with 13 anastomosis groups (AGs) or subspecies detected. The most frequent was Waitea circinata var. circinata (25\%), followed by Rhizoctonia solani AG $3(17 \%)$, $R$. solani AG 4 (14\%), Ceratobasidium sp. AG A (10\%), R. solani AG $8(7 \%)$, Ceratobasidium sp. AG K (6\%), R. solani AG 2-1 (6\%), $W$. circinata var. zeae (6\%), $R$. solani AG 5 (4\%), Ceratobasidium sp. AG G (2\%), R. solani AG $11(2 \%)$, and R. solani AG $1-1 \mathrm{~B}$ and AG 10 (each $<1 \%$ ). However, the distribution of AGs and subspecies varied depending on whether soil or onion plants samples were collected within or adjacent to patches of stunted onion plants. In an attempt to predict the risk of onion stunting for a field prior to planting, DNA concentrations of AG 2-1, AG 3, AG 4, and AG 8 were quantified from bulk soil samples

collected from each of nine growers' fields approximately 1 month before onion sowing in 2012. The preplant DNA concentrations did not show a significant association with the amount of stunting observed in the fields during the growing season. In contrast, the frequency of isolation and DNA concentration of $R$. solani AG 8 detected in soil samples collected during the growing season were greater from inside patches of stunted onion plants than from adjacent healthy areas of an onion crop sampled in 2012, but not for soil samples collected similarly from an onion crop in 2013. AG 2-1, AG 3, and AG 4 DNA concentrations did not differ significantly in soil sampled inside versus outside stunted patches in the fields sampled in 2012 and 2013. Relationships between the number of bulbs harvested or bulb weight versus severity of stunting were defined using correlation and regression analyses for six onion cultivars grown in seven fields surveyed in 2012 and 2013. Onion stunting reduced the average marketable bulb yield by 25 to $60 \%$ within stunted patches of the six cultivars. Stunting did not reduce onion plant stand but consistently reduced the size of bulbs, and yield reduction increased with increasing disease severity.
\end{abstract}

The total area of onion (Allium cepa L.) production in the United States was about 63,000 ha in 2011 (49). Oregon and Washington states rank second and third, respectively, after California for onion bulb production. These two states represent $27 \%$ of the total U. S. onion production area (49), mostly in the semiarid Columbia Basin of north-central Oregon and central Washington. The area of onion production in the Columbia Basin has increased over the past 10 years due to high farm gate values for onion bulb crops, about $\$ 13,500$ / ha, and favorable sandy soils for onion crop production (35). Onions are commonly direct-seeded in spring, from late February to midApril, and planted every 3 to 4 years in rotation with crops such as small cereals, pea (Pisum sativum L.), potato (Solanum tuberosum L.), sweet corn (Zea mays L.), and carrot (Daucus carota L.) crops (35). Strong winds can cause crop losses from sandblasting unless the onion seedlings are protected, e.g., by cereal cover crops (7,8,30). A cereal, typically winter wheat (Triticum aestivum L.), is sown in the fall as a windbreak or cover crop, and killed in the spring with an herbicide application when the cover crop is tall enough to provide a wind barrier to protect onion seedlings against sandblasting without competing with the onion seedlings. The dying roots of the cereal cover crop provide a substrate on which Rhizoctonia spp. grow rapidly in the soil (3), leading to an increase in inoculum for infection

Corresponding author: Lindsey J. du Toit, Email: dutoit@wsu.edu

*The $\boldsymbol{e}$-Xtra logo stands for "electronic extra" and indicates that 2 supplementary tables are included in the online edition.

Accepted for publication 10 November 2014.

http://dx.doi.org/10.1094/PDIS-05-14-0441-RE

(C) 2015 The American Phytopathological Society of onion seedlings. Infection of onion roots results in patches of stunted onion plants $(30,38)$.

Rhizoctonia spp. are common soil inhabitants that are separated into two types, binucleate or multinucleate, based on the number of nuclei per hyphal cell $(25,29)$. A somatic incompatibility or hyphal anastomosis test among isolates of Rhizoctonia spp. is commonly used to separate Rhizoctonia spp. into distinct taxonomic groups called anastomosis groups (AG) (4). Binucleate Rhizoctonia spp. belong to the teleomorph Ceratobasidium Rogers, for which there are 17 described AGs (AG A to AG S), with AG B further classified into three subgroups $(14,25,43)$. Multinucleate Rhizoctonia spp. have at least three nuclei per cell, and include the teleomorphic forms Thanatephorus Donk and Waitea Warcup and Talbot $(14,43,45)$. The anamorph $R$. solani belongs to the teleomorph Thanatephorus. $R$. solani has been grouped further into 14 AGs (AG 1 to AG 13, and AG BI). AGs 1, 2, 3, 4, 6, 8, and 9 have been subdivided further based on morphology, host range, thiamine requirement, pectic enzymes (zymogram groups, ZGs), and molecular characteristics $(14,43,45)$. Other multinucleate species include $R$. oryzae (teleomorph Waitea circinata var. oryzae) and $R$. zeae (teleomorph W. circinata var. zeae) (14).

A number of taxonomic groups within Rhizoctonia spp. have been attributed to cause onion stunting in different parts of the world $(9,11,18,30,52)$. Recently, Patzek et al. (30) characterized 45 isolates collected from onion fields in the Columbia Basin with stunted patches. The isolates were identified as Ceratobasidium AG A, AG E, and AG I; and $R$. solani AG 2-1, AG 3, AG 4, AG 5, AG 8, and AG 9; as well as W. circinata var. circinata and W. circinata var. zeae. $R$. solani AG 4 was the most frequently isolated group (18\% of isolates), followed by AG 8 (16\%) and AG 3 (13\%). AG 8 isolates consistently caused onion stunting, and were the most virulent at relatively low inoculum densities. Isolates of AG 3 and AG E 
were comparatively less virulent than those of AG 8, but more virulent than isolates of AG 2-1, AG 4, and W. circinata var. circinata. Wicks et al. (52) tested potential fungal and nematode pathogens isolated from stunted onion patches in South Australia in an attempt to determine the cause of stunting. They demonstrated that $R$. solani AG 8 and AG 2-1 isolates caused severe onion stunting in growth chamber studies. However, only $R$. solani AG 8 DNA levels from soil sampled within patches were associated significantly with onion stunting. They observed no significant correlation between DNA levels of $R$. solani AG 2-1 and AG 3 with onion stunting in southern Australia. Onion fields in the Columbia Basin (38) and southern Australia (52) in which stunting has been observed either were grown in rotation with cereals or cereals were used as cover crops to protect onion seedlings. There is history of a similar stunting disease of wheat and barley, called bare patch, caused by $R$. solani AG- 8 in the Columbia Basin (32) and southern Australia (24).

In contrast to the Columbia Basin and southern Australia, studies completed in Turkey showed that isolates of $R$. solani AG 4 were more virulent for reducing onion plant height and root weight than isolates of $W$. circinata var. zeae or Ceratobasidium AG B (9). The isolates were obtained from onion roots and rhizosphere soil. The most frequent species was W. circinata var. zeae (69\% of 42 isolates), followed by $R$. solani AG 4 (29\%) and Ceratobasidium AG B (2\%) (9). In New Zealand, $R$. solani AG 3 isolates from potato tubers caused the most severe root rot on onion, followed by isolates of $\mathrm{AG}$ 5, AG 4, AG 2-2IIIB, AG D, AG K, AG E, AG C, AG 8, and AG Bi (11). In Israel, AG 1-2 and AG 4 isolates were pathogenic, whereas AG 3, AG 5, and AG 6 isolates were nonpathogenic on onion (18). Although onion plants can be infected to varying degrees by Ceratobasidium AGs (AG B AG C, AG D, AG E, and AG K), Rhizoctonia AGs (AG 2-1, AG 2-2, AG 3, AG 4, AG 5, AG 6, and AG 8), and W. circinata var. circinata and W. circinata var. zeae, as noted above, isolates of AG E, AG 2-1, AG 3, AG 4, and AG 8 can cause different severity of onion stunting. Among these AGs, isolates of AG 8 were associated most consistently and were more virulent at causing onion stunting in cereal-onion cropping systems than the other AGs $(2,30,52)$.

Root symptoms caused by $R$. solani AG 8 include pinched-off roots or "spear tipping," which leads to stunted onion seedlings evident as early as the first true leaf stage of growth $(7,8)$. In general, patches of stunted onions are most commonly observed at the threeto five-true leaf stage of growth in spring-sown onions, whereas stunted patches in fall-sown onion crops may appear at the six- to seven-true leaf stage in early spring. Circular or irregular patches can range from $<1$ to $>25 \mathrm{~m}$ in diameter, and patches may encompass up to $15 \%$ of the crop area in severely infected fields $(7,8,52)$. Patches often develop adjacent to or along strips of the dead cereal cover crop, and usually have distinct borders between stunted and adjacent healthy plants. As the onion plants grow, stunted plants do not catch up in height with noninfected plants, resulting in reduced bulb yields. The reduction in yield is attributed to a reduction in mean bulb size rather than the number of bulbs $(2,8,39)$. The objectives of this research were to: (i) identify Rhizoctonia and Rhizoctonia-like spp. present within and outside patches of stunted onion plants in grower-cooperator fields in the Columbia Basin of Oregon and Washington States, and (ii) quantify the relationship between severity of onion stunting caused by Rhizoctonia spp. and bulb yield for cultivars commonly grown in this region. Preliminary results have been presented $(8,39,40)$.

\section{Materials and Methods}

Collection of Rhizoctonia and Rhizoctonia-like isolates. Soil and plants samples were collected from onion bulb crops in the semiarid Columbia Basin of central Washington ( $n=17$ fields) and northcentral Oregon ( $n=12$ fields) from 2010 to 2013. All but two were grower-cooperator fields. The fields ranged from 40 to 60 ha, and were irrigated by center-pivot. Soil and plant samples were collected mostly from the three- to six-true-leaf stage of growth from inside and outside patches of stunted onion plants, where it was evident the stunting was caused by Rhizoctonia spp. (30). Soil samples (3 to 10 per field) were collected to a $15 \mathrm{~cm}$ depth with a shovel. The toothpick method of baiting was employed to isolate Rhizoctonia and Rhizoctonia-like spp. from each individual soil sample, as described by Paulitz and Schroeder (31). From each of 3 to 5 plant samples per field, the roots and basal plate of each onion plant were rinsed gently in sterilized distilled water, blotted dry, and sections (each approximately $1 \mathrm{~cm}$ long) plated onto $2 \%$ water agar. Putative Rhizoctonia and Rhizoctonia-like spp. were identified using a dissecting microscope (Olympus SZ, $10 \times$ to $40 \times$ magnification) after 12 to $48 \mathrm{~h}$ of incubating the plant tissue at ambient temperature $\left(24 \pm 2^{\circ} \mathrm{C}\right)$. A hyphal tip of each putative Rhizoctonia or Rhizoctonia-like sp. was excised from the mycelium and transferred onto a plate of potato dextrose agar (PDA) medium (Difco, Sparks, MD). After about 7 days, each isolate was then transferred to a PDA slant for long-term storage at $4^{\circ} \mathrm{C}$, and to $15 \mathrm{ml}$ potato dextrose broth (PDB) (Difco) in a petri dish for generating a broth culture for DNA extraction. The PDB culture was incubated at ambient temperature for about 5 days, the mycelial mat rinsed three times in sterilized distilled water, and the mycelium blotted dry on sterilized Whatman No. 1 filter paper. The mycelium was then stored at $-20^{\circ} \mathrm{C}$ in a $1.5-\mathrm{ml}$ Eppendorf tube until DNA was extracted.

DNA extraction, PCR assay, and AG determination. Genomic DNA was extracted from mycelium of each Rhizoctonia or Rhizoctonialike isolate using a FastDNA kit (MP Biomedicals, Santa Ana, CA) and a FastPrep-24 (MP Biomedicals) following the manufacturer's protocols. Extracted genomic DNA was stored in a $0.6-\mathrm{ml}$ Axygen microtube (Genesee Scientific, San Diego, CA) at $-20^{\circ} \mathrm{C}$. The universal eukaryotic primers UN-UP18S42 (5'-CGTAACAAG GTTTCCGTAGGTGAAC-3') and UN-LO28S576B (5'-GTTTC TTTTCCTCCGCTTATTAATATG-3') were used to amplify the ITS $1+5.8 \mathrm{~S}+$ ITS2 region of rDNA by PCR assay (30). PCR premixes for forward sequencing of ITS rDNA were prepared following the protocol of Elim Biopharmaceuticals, Inc. (Hayward, CA), and sent for sequencing by this company. Manual sequence editing was performed with Chromas Lite Version 2.1 (Technelysium Pty. Ltd., South Brisbane, Australia). Edited ITS sequences $\geq 100 \mathrm{bp}$ were searched for similar sequences with an appropriate set of reference sequences from the NCBI BLAST database (http:// blast.ncbi.nlm.nih.gov). BLAST results with sequence identity $\geq 98 \%$ were used to determine species, subspecies, and AG of each isolate.

DNA quantification of $\boldsymbol{R}$. solani AGs in soil. Soil samples were collected in early spring (29 February to 3 March) of 2012 from three fields on each of three farms (Farm A near Boardman, OR; Farm B near Paterson, WA; and Farm C near Pasco, WA) to assess the relationship between DNA concentration of AG 2-1, AG 3, AG 4, and AG 8 isolates of $R$. solani detected in soil just prior to onion seeding with severity of onion stunting observed in the onion crops later that season. Soil samples were collected from fields with: i) no history of stunted patches, ii) a history of moderate stunting, and iii) a history of severe stunting based on growers' records and aerial, infrared images of previous onion crops. About $1 \mathrm{~kg}$ of soil was collected to a depth of $10 \mathrm{~cm}$ from each of three transects of each field (the fields each averaged about 50 ha) just before the cereal cover crop was killed with a herbicide application. The soil samples $(9$ fields $\times 3$ sections/field $=$ 27 soil samples in total) were dried overnight at $45^{\circ} \mathrm{C}$. About $450 \mathrm{~g}$ of dried bulk soil of each sample was sent to the South Australia Research and Development Institute (SARDI) in Urrbrae, Australia, for quantification of the DNA of Rhizoctonia AGs. This facility has developed a proprietary protocol for extracting and quantifying DNA from as much as $450 \mathrm{~g}$ soil/sample $(28,44)$. Based on SARDI standard soil samples, soils with $>120 \mathrm{pg}$ DNA of $R$. solani AG 8/g soil pose a severe risk of onion stunting, soils with 50 to $120 \mathrm{pg}$ DNA/g soil have a medium risk of stunting, and soils with $<50 \mathrm{pg}$ DNA/g soil are categorized as low risk (S. Anstis, personal communication).

In both 2012 and 2013, soil samples were collected from inside and outside stunted patches of onion plants in various grower-cooperator fields, air dried as described above, and shipped to SARDI for quantifying DNA of $R$. solani AG 2-1, AG 3, AG 4, and AG 8. In 2012, soil 
samples were collected from inside and outside each of five stunted patches from each of six fields: one field at Farm A, two fields at Farm B, two fields at Farm C, and one field at Farm D (Farms A, $\mathrm{B}$, and $\mathrm{C}$ were the same farms noted above, and Farm D is near George, WA). For the soil samples collected from inside stunted patches in June, Rhizoctonia spp. were isolated by the toothpick baiting method from four patches in the field at Farm A and from three patches in one of the two fields surveyed at Farm B. In addition, five soil samples were collected during the first week of July 2012 from each of five patches from one of the two fields sampled at Farm C, and 14 soil samples were collected that week from inside and outside each of four patches in a field at Farm A and three patches in a field at Farm B, to assess changes in AGs detected and quantified in June versus July 2012. A total of 79 soil samples were collected in 2012.

In 2013, soil samples were collected from inside and outside of patches of stunted onion plants that ranged in severity ratings from 1 to 3 , where: $1=$ a majority of onion plants in the stunted patch were stunted $<33 \%$ compared with adjacent, healthy plants outside the patch; $2=$ a majority of onion plants were stunted 33 to $66 \%$; and $3=$ a majority of onion plants were stunted $>66 \%$. This was done for three patches/severity rating in each of one field at Farm A and three fields at Farm B in the fourth week of June, for a total of 72 soil samples collected in 2013.

Yield loss assessment. The effects of onion stunting on the yield of onion bulb crops were measured in three and four fields in the Columbia Basin in 2012 and 2013, respectively (Table 1). The onion crop in each field was spring-sown with a long-day onion cultivar typical for the semiarid, inland Pacific Northwest. Within each year, each field ranged from 40 to 60 ha, was maintained by a different grower-cooperator, and was irrigated by center-pivot. Patches of stunted onion plants that were $>1.5 \mathrm{~m}$ long and at least two beds wide were selected for yield assessment in each onion field at the five- to seven-true leaf growth stage. Five patches were selected in each field for each of the three stunting severity ratings described above. In both years, bulbs were harvested manually from inside and outside each patch in each field within a few weeks of the grower-cooperator harvesting the entire onion bulb crop (Table 1). Bulbs were harvested from $1.5 \mathrm{~m}$ of each of two double rows within each patch, and from an equal area adjacent to each patch. Bulbs harvested from each patch and the adjacent healthy area were bagged separately and graded by size: colossal $(>10.2 \mathrm{~cm}$ diameter), jumbo (7.6 to $10.2 \mathrm{~cm})$, medium $(5.7$ to $7.6 \mathrm{~cm})$, prepack $(<5.7 \mathrm{~cm})$, and culled (nonmarketable because of split basal plates, double bulbs, green shoulders, rot, etc.) bulbs. The total number of bulbs in each size category was counted, and the total bulb weight/size category calculated. Bulbs of each size, except the culled bulbs, were considered marketable.

Data analysis. The total number of isolates and frequency of isolation of multinucleate and binucleate Rhizoctonia species, subspecies, and AGs were determined. The number of these fungi was categorized further into groups based on the location in the fieldthose isolated from soil and plants sampled within versus outside stunted patches of onion plants, or isolated randomly from soil across the field. The isolates also were classified based on whether they were obtained from soil using the toothpick baiting method or isolated directly from onion basal plates and roots.

For onion bulb yield loss assessment, the number and weight of bulbs in each size category was calculated as a percentage of bulbs harvested from within or outside each patch. The percentage change in number and weight of bulbs for each size category compared with the number and weight of bulbs of each size category harvested outside each patch was calculated for patches of each severity rating in each field surveyed. The percentage reduction in number and weight of colossal, jumbo, and medium bulbs, as well as total marketable bulbs and total bulbs of all size categories were calculated. The percentage increase in prepack and culled bulbs inside versus outside each patch of stunted plants was also computed.

The relationship between severity of onion stunting and percentage change in number or weight of onion bulbs for each cultivar (field) was calculated using regression analyses with JMP Version 11 Pro (SAS Institute Inc., Cary, NC). The intercept and slope of each regression equation represented the relative change in yield as a percentage of the unit change in disease severity from mild stunting (severity rating of 1 ) to severe stunting (rating of 3 ). Normality of the residuals and homogeneity of the variances across disease severity ratings were tested to meet the assumptions for parametric regression analyses. If any of the assumptions was not satisfied statistically, the data were transformed as suggested by the Box-Cox transformation of JMP for subsequent regression analysis. Mean changes in yield were calculated for each field by disease severity rating, and regression analyses were calculated to quantify yield loss across all cultivars (fields) for each year, and combined over the two years.

\section{Results}

Diversity of Ceratobasidium spp., Rhizoctonia spp. anastomosis groups (AG), and Waitea circinata subspecies. Out of 12 onion fields surveyed in Oregon and 17 fields surveyed in Washington, binucleate and multinucleate Rhizoctonia spp. were isolated from 10 fields in each state (data not shown). Although Rhizoctonia spp. were not recovered from the other fields surveyed in each state, the exact cause of stunting in those fields was not verified. A total of $251 R \mathrm{Ri}$ zoctonia or Rhizoctonia-like species was identified with ITS sequences $\geq 100 \mathrm{bp}$ and sequence identity $\geq 98 \%$ with the ITS sequences of reference isolates in GenBank. Details of the individual isolates of Ceratobasidium, Rhizoctonia, and Waitea species and anastomosis groups (AG) are provided in Supplementary Table 1. Among these isolates, multinucleate Rhizoctonia spp. were more frequent $(82 \%$ of all isolates) than binucleate Ceratobasidium spp. (18\%). Among the isolates of $R$. solani, W. circinata, and Ceratobasidium spp., $R$. solani was the most frequent $(51 \%)$, followed by $W$. circinata (31\%) and Ceratobasidium spp. (18\%). A total of 13 AGs or subspecies was identified, including Ceratobasidium spp. AG A, AG G, and AG K; R. solani AG 1-1B, AG 2-1, AG 3, AG 4, AG 5, AG 8, AG 10, and AG 11 ; and W. circinata var. circinata and W. circinata var. zeae (Fig. 1). The most frequent AGs or subspecies detected were

Table 1. Onion bulb yield loss assessment caused by stunting from Rhizoctonia and Rhizoctonia-like fungi in grower-cooperator fields in the Columbia Basin of Oregon and Washington in 2012 and 2013

\begin{tabular}{|c|c|c|c|c|c|c|c|}
\hline$\overline{\text { Year }}$ & Cultivar & Seed company ${ }^{a}$ & Planting date & Harvest date & Bed width $(\mathbf{c m})^{b}$ & Field $^{c}$ & City, state ${ }^{\mathrm{d}}$ \\
\hline \multirow[t]{3}{*}{2012} & Mercury & Monsanto Vegetable Seeds, Parma, ID & 13 March & 1 August & 110 & B-238 & Paterson, WA \\
\hline & Cometa & $\begin{array}{l}\text { Bayer CropScience Vegetable Seeds, } \\
\text { Brooks, OR }\end{array}$ & 8 April & 21 August & 85 & C-R7 & Pasco, WA \\
\hline & Tamara & Bejo Seeds, Inc., Oceano, CA & 16 March & 27 August & 100 & A-R44 & Boardman, OR \\
\hline \multirow[t]{4}{*}{2013} & Frontier & American Takii, Salinas, CA & 8 March & 19 July & 110 & B-240 & Paterson, WA \\
\hline & Redwing & Bejo Seeds, Inc. & 21 March & 27 August & 110 & B-417 & Paterson, WA \\
\hline & Legend & Bejo Seeds, Inc. & 28 March & 26 August & 110 & B-774 & Plymouth, WA \\
\hline & Redwing & Bejo Seeds, Inc. & $21 \mathrm{March}$ & 27 August & 85 & A-756 & Boardman, OR \\
\hline
\end{tabular}

\footnotetext{
a Seed company that produces the cultivar.

${ }^{b}$ Each bed included two double-rows of onion plants.

c Grower-cooperator onion field in which yield loss assessment was completed.

d Nearest town or city to the field in which yield loss assessment was completed, and the state in which the field was located.
} 
W. circinata var. circinata $(25 \%), R$. solani AG $3(17 \%), R$. solani AG $4(14 \%)$, and Ceratobasidium AG A (10\%). Only $7 \%$ of the isolates were $R$. solani AG 8 , followed by $6 \%$ of the isolates belonging to each of Ceratobasidium AG K, $R$. solani AG 2-1, and W. circinata var. zeae, $4 \%$ belonged to $R$. solani AG 5 , and $2 \%$ belonged to Ceratobasidium $\mathrm{AG} \mathrm{G}$ and $R$. solani AG 11 . Only two isolates of $R$. solani AG 1-1B and one isolate of $R$. solani AG 10 were identified, comprising $<1 \%$ of the 251 isolates (Fig. 1).

Of the 251 isolates obtained from plant and soil samples, 176 (70\%) were obtained from within stunted patches, 57 (23\%) adjacent to (outside) stunted patches, and $18(7 \%)$ sampled randomly across the fields (Fig. 2). A large majority of the isolates $(170=68 \%)$ was baited from soil samples, $61(24 \%)$ were isolated from onion basal plates, and $20(8 \%)$ were obtained from onion roots. The taxonomic groups of AGs or subspecies detected within and outside stunted patches were similar (Fig. 2A and B). One hundred and sixteen isolates of AG A, AG K, AG 2-1, AG 3, AG 4, AG 5, AG 8, W. circinata var. circinata, and W. circinata var. zeae were detected in soil sampled within patches (Fig. 2A). Of these, the most frequent was $W$. circinata var. circinata (39 isolates or $34 \%$ of 116) followed by AG $3(20 \%)$. Of the isolates obtained from onion basal plates within patches, 46 were of AG A, AG K, AG 2-1, AG 3, AG 4, AG 5, AG 8, AG 11,W. circinata var. circinata, and W. circinata var. zeae (Fig. 2A). The most frequent subgroups detected were AG A (19 of 46 isolates $=41 \%)$ and AG $4(20 \%)$. Fourteen isolates comprising those of AG K, AG 3, AG 4, AG 8, AG 10, and W. circinata var. circinata were obtained from onion roots within patches (Fig. 2A). Of the 14 isolates, AG 4 and AG 8 were isolated six and three times, respectively.

Isolates baited from soil in healthy areas adjacent to stunted patches included 36 isolates of AG A, AG K, AG 2-1, AG 3, AG 5 , AG 8,W. circinata var. circinata, and W. circinata var. zeae (Fig. 2B). Among these, $W$. circinata var. circinata (13 of 36 isolates $=$ $36 \%)$ followed by AG $3(20 \%)$ were most common. Rhizoctonia spp. were also isolated from the basal plates of onion plants collected from healthy (nonstunted) areas of the fields (Fig. 2B). Fifteen isolates of $\mathrm{AG} \mathrm{A}, \mathrm{AG} \mathrm{K}, \mathrm{AG} 3$, and $\mathrm{AG} 4$ were obtained from basal plates, with AG K and AG 4 predominant (six and four isolates, respectively). Four isolates of AG G and two isolates of AG 1-1B were obtained from onion root samples collected from healthy areas of the fields (Fig. 2B). A total of 18 isolates comprising AG 3, AG 4, AG 5, AG 8 , and W. circinata var. circinata was obtained from soil samples collected randomly across the fields, with seven isolates of AG 3 , and five isolates of $W$. circinata var. circinata (Fig. 2C).

W. circinata var. circinata isolates were detected most frequently from soil sampled within and outside stunted patches in the onion

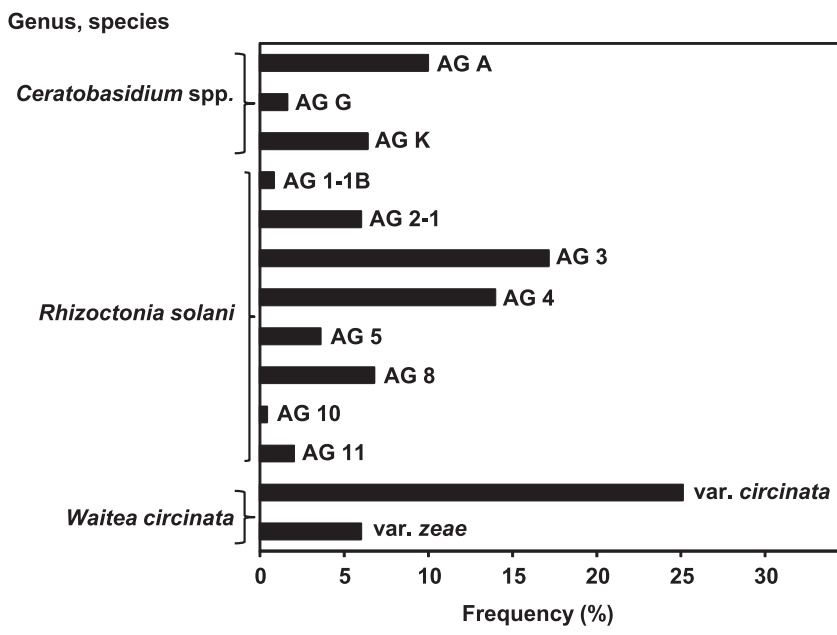

Fig. 1. Frequency of Ceratobasidium spp., Rhizoctonia solani anastomosis groups (AGs), and Waitea circinata subspecies $(n=251)$ obtained from 29 onion fields surveyed in the Columbia Basin of Oregon and Washington states in 2010 to 2013. fields surveyed, followed by AG 3 in soil sampled from within patches and W. circinata var. zeae in soil sampled outside patches (Fig. 2A and B). Other common AGs included AG A, AG K, AG 2-1, AG 5, AG 8, and W. circinata var. zeae. Isolates of AG 4 were detected only in soil sampled within patches. Isolates of AG 10 were obtained only from within patches and only from onion roots (Fig. 2A). On onion basal plates, Ceratobasidium AGs were most predominant both within and outside patches. From the basal plate of plants sampled inside the patches, AG A, AG 4, W. circinata var. circinata, AG 11, AG 3, AG K, AG 8, W. circinata var. zeae, AG 2-1, and AG 5 (in decreasing order) were isolated. AGs isolated from basal plates from healthy areas of the fields were AG A, AG K, AG 3, and AG 4. Among the root isolates, $R$. solani AG $4, \mathrm{AG} 8, \mathrm{AG} 3$, and AG 10 isolates were obtained most frequently (in decreasing order) from onion roots sampled within the stunted patches, whereas Ceratobasidium AG G isolates were present only on roots sampled outside the patches (Fig. 2A and B).

Quantification of DNA of $R$. solani AGs in soil. DNA concentrations of $R$. solani AG 2-1, AG 3, AG 4, and AG 8 in soil samples collected in early spring 2012 were not correlated significantly with the history of low, moderate, or high risk of onion stunting as perceived by the grower-cooperators for the nine fields sampled, or with the incidence/severity of stunting observed in onion crops planted in those fields approximately 4 months after the initial soil sampling (May to July 2012) (data not shown). DNA of $R$. solani AG 8 was only detected in 4 of the 27 soil samples ( 2 of the 9 fields, with soil collected along 3 transects per field), and was not detected in any of

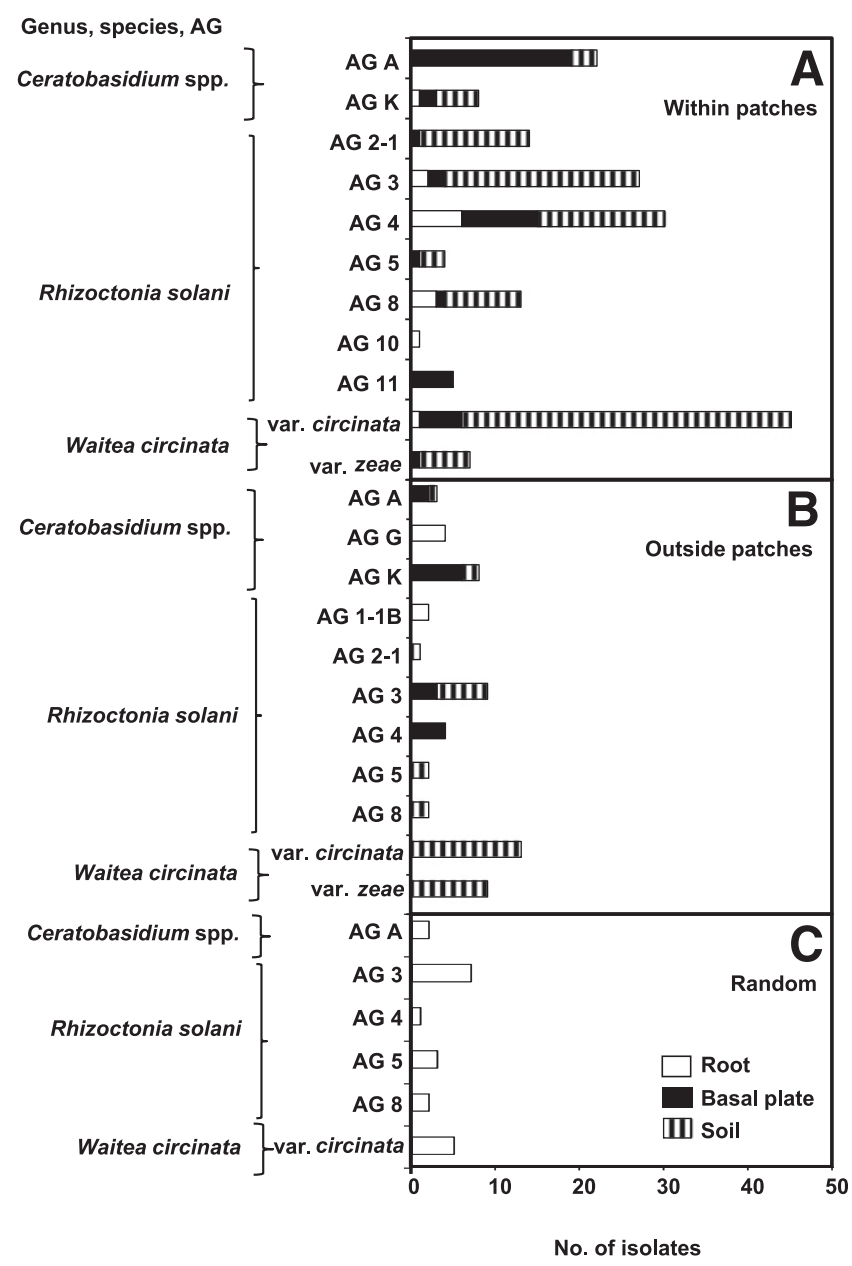

Fig. 2. Number of isolates of Ceratobasidium spp., Rhizoctonia solani anastomosis groups (AG), and Waitea circinata subspecies obtained from onion roots, onion basal plates, and soil collected from within $(\mathbf{A})$ and outside $(\mathbf{B})$ patches of stunted onion plants, and sampled randomly across onion fields (C) in the Columbia Basin of Oregon and Washington states in 2010 to 2013 (total number of isolates $=251$ ). 
the fields with a medium historical risk of onion stunting. Out of four soil samples representing two fields in which AG 8 DNA was detected, one field had a low risk of onion stunting based on the grower's historical records, and the other three samples were from one field that had a severe history of onion stunting. However, the latter field did not develop severe stunted patches in the onion crop four months after soil sampling (June 2012). R. solani AG 4 DNA was detected in all nine of the fields sampled, including from eight, four, and seven soil samples from fields with low, moderate, and high risks of stunting, respectively. The greatest concentration of AG 4 DNA (10-fold greater than in other fields sampled) was in the same samples from which AG 8 DNA was detected and for which severe onion stunting did not develop that season. The greatest concentration of AG 2-1 DNA was from fields with moderate (two fields) or severe (one field) perceived risk of onion stunting. Also, the AG 3 DNA concentration detected did not correlate significantly or consistently with the level of perceived risk of stunting or observed severity of stunting in 2012.

Quantification of DNA of each of four $R$. solani AGs from 79 soil samples collected in June to July 2012 revealed that AG 8 DNA was present at a greater frequency ( $41 \%$ of all samples in June and July) compared with DNA of AG 4 (25\%), AG 2-1 (9\%), and AG 3 (6\%). From the samples collected from the same patches in June and July, the frequency of AG 8 DNA detected was greater inside versus outside stunted patches in both June (86 versus $14 \%$, respectively) and July (57 versus $43 \%$, respectively) (Fig. 3 ). Similarly, AG 3 DNA was detected in $43 \%$ of soil samples from within patches in June but from none of the soil sampled outside patches in June, and was not detected in any of the soil samples collected in July. In June, DNA of AG 4 was detected at a greater frequency in soil sampled inside versus outside stunted patches (43 versus 29\%, respectively), but at very similar frequencies from soil sampled inside versus outside patches in July (14 and 14\%, respectively). DNA of AG 2-1 was only detected from inside patches in June (14\%) but only from outside patches in July (14\%) (Fig. 3). Among the Rhizoctonia spp. recovered from within stunted patches in June 2012, DNA of AG 8 was consistently detected at a greater frequency inside versus outside the patches sampled in both June and July (Fig. 3). However, the frequency of samples from which AG 8 DNA was detected decreased in July compared with June. Similar trends were evident for DNA of AG 3 and AG 4 for soil sampled in June versus July, but not for AG 2-1 (Fig. 3).

A greater difference in concentration of DNA detected inside versus outside stunted patches of onion plants was observed for $R$. solani AG 8 (915 versus 88 pg DNA/g soil, respectively) followed by AG 3 (712 versus 585 pg DNA, respectively) in 79 soil samples collected in 2012. The concentration of DNA of AG 4 (1,121 pg/g soil) and AG 2-1 (8 pg/g soil) detected in soil from healthy areas of the fields

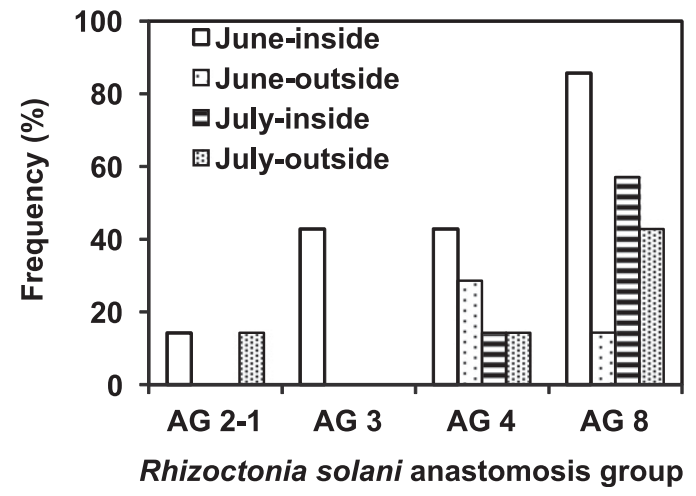

Fig. 3. Frequency (\%) of Rhizoctonia solani anastomosis groups (AGs) detected in soil samples collected from inside and outside patches of stunted onion plants in growers' onion crops in the Columbia Basin of Oregon and Washington states in June and July 2012, and quantified by real-time PCR assay. July soil samples were collected from inside the same patches of stunted onion plants from which Rhizoctonia spp. were isolated in June using a toothpick baiting method (31). adjacent to stunted patches was greater than in soil sampled from within stunted patches (395 and $4 \mathrm{pg} / \mathrm{g}$ soil, respectively). Based on the SARDI standards for DNA concentrations of $R$. solani AG 8 , a high risk of stunting was observed for only $5 \%$ of the 42 soil samples collected inside stunted patches, and a medium risk was detected for only $7 \%$ of the soil samples collected inside the patches (data not shown). Of the remaining soil samples collected inside the patches, 38 and $50 \%$ had low risk or no detectable risk, respectively. None of the AG 8 DNA concentrations detected in soil samples collected outside the patches posed a high or medium risk of onion stunting. For the 37 soil samples collected outside the patches, the DNA concentration of AG 8 was below the detection limit in $86 \%$ of the samples, and $14 \%$ of the soil samples had a low risk of stunting (data not shown).

Out of 72 soil samples analyzed for DNA quantification of AGs in 2013, $R$. solani AG 8 DNA was detected in only 15 samples (data not shown). However, $R$. solani AG 8 DNA was detected at the greatest frequency of the four AGs for which DNA was quantified, followed by AG 3 DNA. $R$. solani AG 2-1 and AG 4 DNA were not detected in any of the soil samples. In general, DNA quantification of $R$. solani AGs from the soil samples was inconsistent. The DNA concentrations were not correlated significantly with the growers' perceived historical severity of onion stunting (measured in soil samples collected in early March 2012), or the severity of stunting observed in the 2012 onion crops at the five- to seven-true leaf stage of growth for soil samples collected in June 2013. The concentration of AG 8 DNA detected was not associated significantly with the incidence of stunted patches or severity of stunting because, out of 15 soil samples from which AG 8 DNA was detected, 14 samples were from healthy areas adjacent to stunted patches. The greatest level of risk posed by AG 8 DNA detected in the soil samples was a medium risk, from soil samples collected from healthy areas adjacent to stunted patches. The other samples from which AG 8 DNA was detected were classified as having a low risk of onion stunting.

Correlation between severity of onion stunting and bulb yield. Generally, the number of bulbs harvested within stunted patches did not differ significantly from the number of bulbs harvested from adjacent, healthy areas of each of three and four grower-cooperator onion fields evaluated in 2012 and 2013, respectively (data not shown), i.e., stunting did not affect onion plant stands. However, bulb size was affected significantly by onion stunting, with a greater impact on bulb size the more severely the plants were stunted (Fig. 4). A greater number of large bulbs (colossal and jumbo) were present in healthy areas of the fields (stunting rating of 0 ) than in the stunted patches (Fig. 4A and C). In contrast, the number of medium and prepack bulbs increased as the severity of stunting increased. Although the total number of marketable bulbs was similar among patches with different severity ratings, total bulb weight and total marketable bulb weight decreased as disease severity increased (Fig. 4B and D). Total onion bulb yield loss ranged from 10 to $46 \%$ in patches with a severity rating of 1 , from 24 to $57 \%$ in patches with a severity rating of 2 , and from 40 to $76 \%$ in patches with a severity rating of 3 . The percentage reduction in total marketable bulb weight in patches with a disease severity rating of 1 ranged from 10 to $47 \%$, in patches with a severity rating of 2 ranged from 24 to $57 \%$, and in patches with a severity rating of 3 ranged from 40 to $78 \%$ across the seven fields evaluated in 2012 and 2013 (data not shown). The average loss in total bulb weight and marketable bulb weight in the stunted patches was 41 and $42 \%$ in 2012 and 2013, respectively, compared with nonstunted areas of the fields.

When the yield data were analyzed by cultivar, severity of onion stunting was significantly positively correlated with a reduction in number and weight of jumbo bulbs for all cultivars evaluated except Cometa, and significantly positively correlated with a reduction in total bulb weight and marketable bulb weight for all cultivars in both years (Supplementary Table 2). The percentage reduction in number and weight of colossal bulbs was not significantly correlated with severity of onion stunting for any of the cultivars evaluated in 2012 or 2013, because very few colossal bulbs were harvested even from the nonstunted areas of these fields. Similarly, onion stunting severity 
was not correlated significantly with the number or weight of prepack and culled bulbs for any of the cultivars in both years because of the low number of bulbs of these categories. In 2012, onion stunting severity was significantly positively correlated with a reduction in number and weight of medium bulbs for the cultivar Cometa only. The percentage reduction in number of total bulbs and number of marketable bulbs were positively correlated with severity of onion stunting for Cometa and Mercury, but not for Tamara. In 2013, the percentage reduction in number of medium bulbs was significantly correlated with severity of stunted patches in the field of Legend only. The reduction in number of total bulbs and reduction in number of marketable bulbs were not associated significantly with onion stunting severity in any of the four fields evaluated in 2013. Correlation coefficients calculated for severity of onion stunting and the mean number of bulbs and weight of bulbs in each size category for fields evaluated in 2012, 2013, and combined over the two years revealed the predominant significant associations between disease severity and onion bulb size observed for individual cultivars or fields. In general, onion stunting reduced the number and weight of jumbo bulbs, and the weight but not number of marketable bulbs.
Regressions of severity of onion stunting with onion bulb yield. Onion bulb variables most strongly correlated for all cultivars (fields) with severity of onion stunting were selected to evaluate the best linear regression models for yield loss prediction. Simple linear regression models were calculated for the percentage reduction in number and weight of jumbo bulbs, and percentage reduction in number of marketable bulbs and weight of marketable bulbs for all cultivars in 2012 (Fig. 5) and 2013 (Fig. 6). For the three cultivars (fields) surveyed for the impact of stunting on onion bulb yield in 2012, the number and weight of jumbo bulbs of the cultivar Tamara were impacted most significantly with severity of stunting $\left(\beta_{1}=30.7\right.$ and 26.1 for the slopes of the linear regression equations for number and weight of jumbo bulbs, respectively) (Fig. 5A and B, respectively), followed by the number and weight of Mercury jumbo bulbs ( $\beta_{1}=14.9$ and 11.5 , respectively). The number and weight of Cometa jumbo bulbs did not differ significantly among patches with severity ratings of 1, 2, or 3 (Fig. 5A and B). The regression equations for the number of marketable bulbs of Cometa and Mercury were similarly significant $\left(\beta_{1}=20.8\right.$ and 17.5 , respectively), but was not significant for Tamara (Fig. 5C). In contrast, regression equations for the weight
A Onion stunting severity

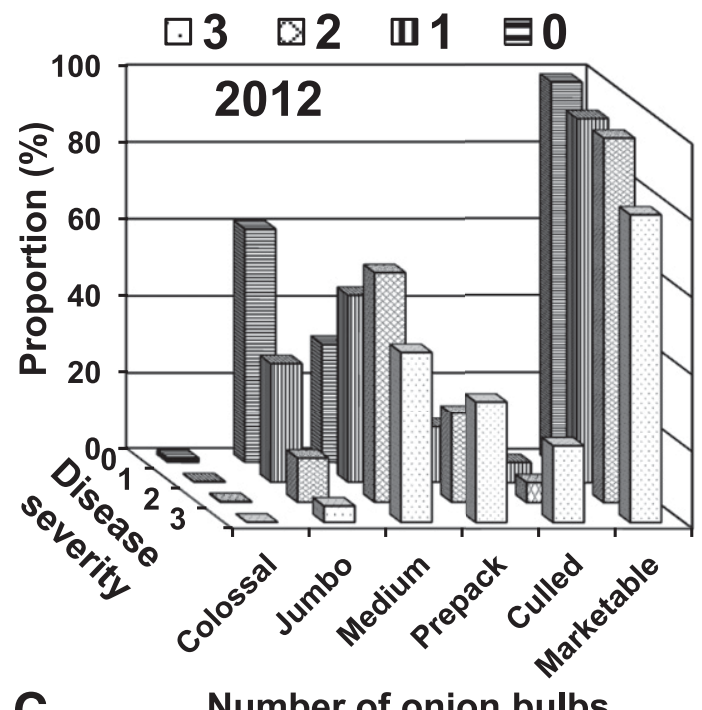

C

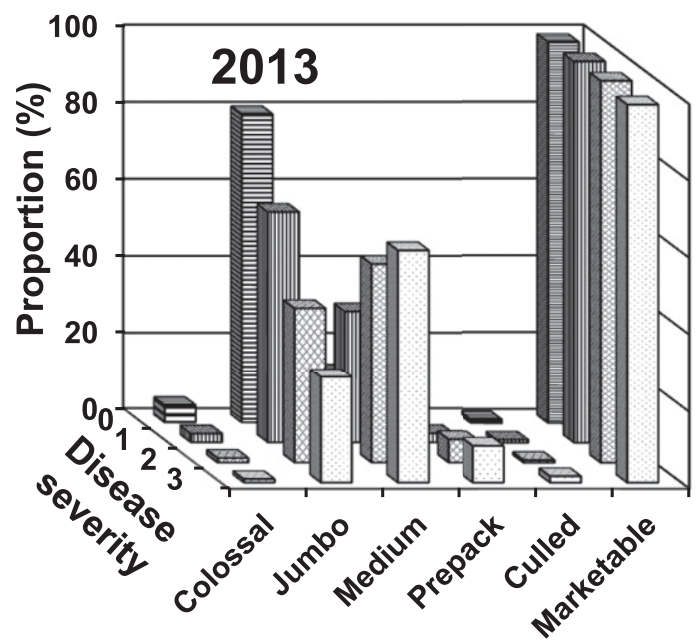

Number of onion bulbs
B
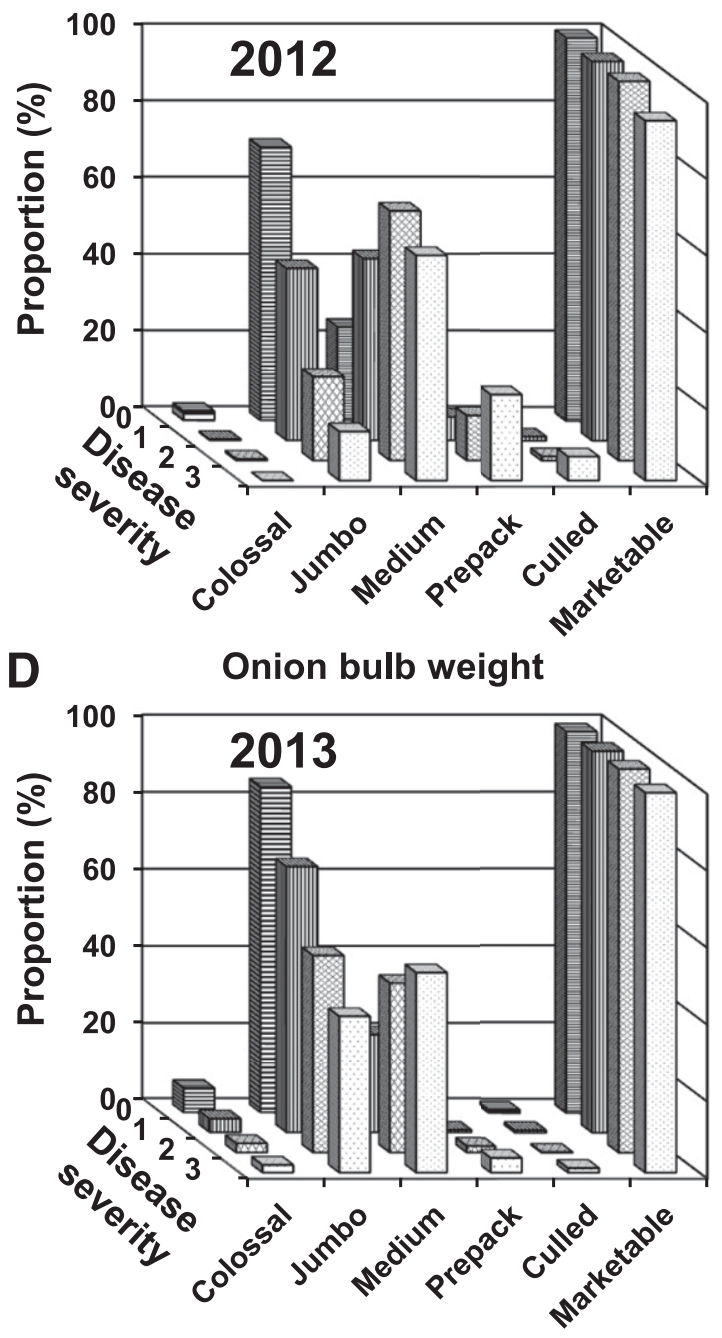

Onion bulb weight

Fig. 4. Proportion of onion bulbs ( $A$ and $\mathbf{C}$ ) and weight of each size category of onion bulbs ( $B$ and $\mathbf{D})$ harvested from onion fields in the Columbia Basin of Oregon and Washington states that had patches of stunted onion plants ranging in severity of stunting from 1 to 3 in 2012 (A and $\mathbf{B}$ ) and 2013 (C and D). The results were calculated by averaging the data from three onion fields evaluated in 2012 ( 5 patches evaluated/severity rating/field) and four fields in 2013 (5 patches/severity rating/field from three of the fields, and 4 patches/ severity rating for the fourth field). Onion stunting severity was rated using a 1 to 3 scale, where: $1=$ a majority of the plants in the patch were stunted $<33 \%$ relative to adjacent, healthy plants outside the patch; 2 = a majority of plants were stunted 33 to $66 \%$; and $3=$ a majority of plants were stunted $>66 \%$. 
of marketable bulbs were significant and similar for all three cultivars ( $\beta_{1}$ ranged from 15.5 to 17.3 for the three cultivars) (Fig. 5D). For the four onion fields surveyed in 2013 for yield loss associated with stunted patches, the slopes of the linear regression equations for reduction in number and weight of jumbo bulbs were similar for all four fields (Fig. 6A and B, respectively). The slope of the linear regression equations $\left(\beta_{1}\right)$ ranged from 14.0 to 24.9 for the number of jumbo bulbs (Fig. 6A), and from 13.4 to 26.3 for weight of jumbo bulbs (Fig. 6B). The number of marketable bulbs was not associated significantly with severity of onion stunting in any of the four fields (Fig. 6C), whereas in all four fields the weight of marketable bulbs was strongly reduced by increasing severity of stunting ( $\beta_{1}$ ranged from 10.4 to 15.6 ) (Fig. 6D).

\section{Discussion}

This study documented the frequency and prevalence of Rhizoctonia or Rhizoctonia-like species in patches of stunted onion plants versus adjacent healthy areas, and quantified the effects of onion stunting on number and weight of bulb sizes in onion crops in the Columbia Basin of Oregon and Washington. The frequency and diversity of AGs and subspecies of binucleate and multinucleate $R$ hizoctonia spp. from inside versus outside patches of stunted plants were determined from 29 center-pivot irrigated onion fields from 2010 to 2013. The presence of 13 AGs or subspecies of Rhizoctonia or Rhizoctonia-like spp. demonstrated the presence of a very diverse set of AGs, including three AGs of Ceratobasidium spp. (AG A, G, and $\mathrm{K}$ ), eight AGs of $R$. solani (AG 1-1B, 2-1, 3, 4, 5, 8, 10, and 11), and two subspecies of $W$. circinata (var. circinata and var. zeae).
However, the frequency and distribution of these AGs or subspecies varied depending on whether soil or onion plant samples were collected within or adjacent to patches of stunted onion plants. This suggests that different AGs or subspecies may be causal agents of onion stunting in the Columbia Basin, as demonstrated in previous studies $(9,11,18,30,52)$.

Onion is generally grown in 3- to 4- year rotations in the Columbia Basin with crops such as cereals, potato, pea, carrot, and sweet corn (35). Rhizoctonia spp. that infect these crops can remain in the soil for relatively long periods $(1,14,43)$. Thus, a diversity of Rhizoctonia groups is expected in onion crops that reflects the diversity of rotation crops, as in other cropping systems $(1,13,23,27,46,48)$. Patzek et al. (30) reported 11 AGs or subgroups of Rhizoctonia or Rhizoctonialike spp. (AG A, E, I, 2-1, 3, 4, 5, 8, 9, W. circinata var. circinata, and $W$. circinata var. zeae) from the Columbia Basin from just 45 isolates collected from three onion fields. In this study of 251 isolates from 29 onion fields in the Columbia Basin, W. circinata comprised $32 \%$ of the isolates, and W. circinata var. circinata ( $R$. oryzae) comprised $25 \%$ of the isolates. The $W$. circinata isolates were the most dominant subgroup, followed by $R$. solani AG 3 (17\%), AG 4 (14\%), and Ceratobasidium AG A (10\%). However, W. circinata was isolated mostly from soil samples. This species readily forms sclerotia (15), which may help the fungus persist in soil even in the absence of a host crop. $R$. oryzae is widely distributed in the inland Pacific Northwest United States where it has been isolated at greater frequency than other AGs in wheat and barley fields $(20,26,34)$. Crops rotated with onion in the Columbia Basin, such as wheat, barley (Hordeum vulgare L.), and pea (35), are also susceptible to
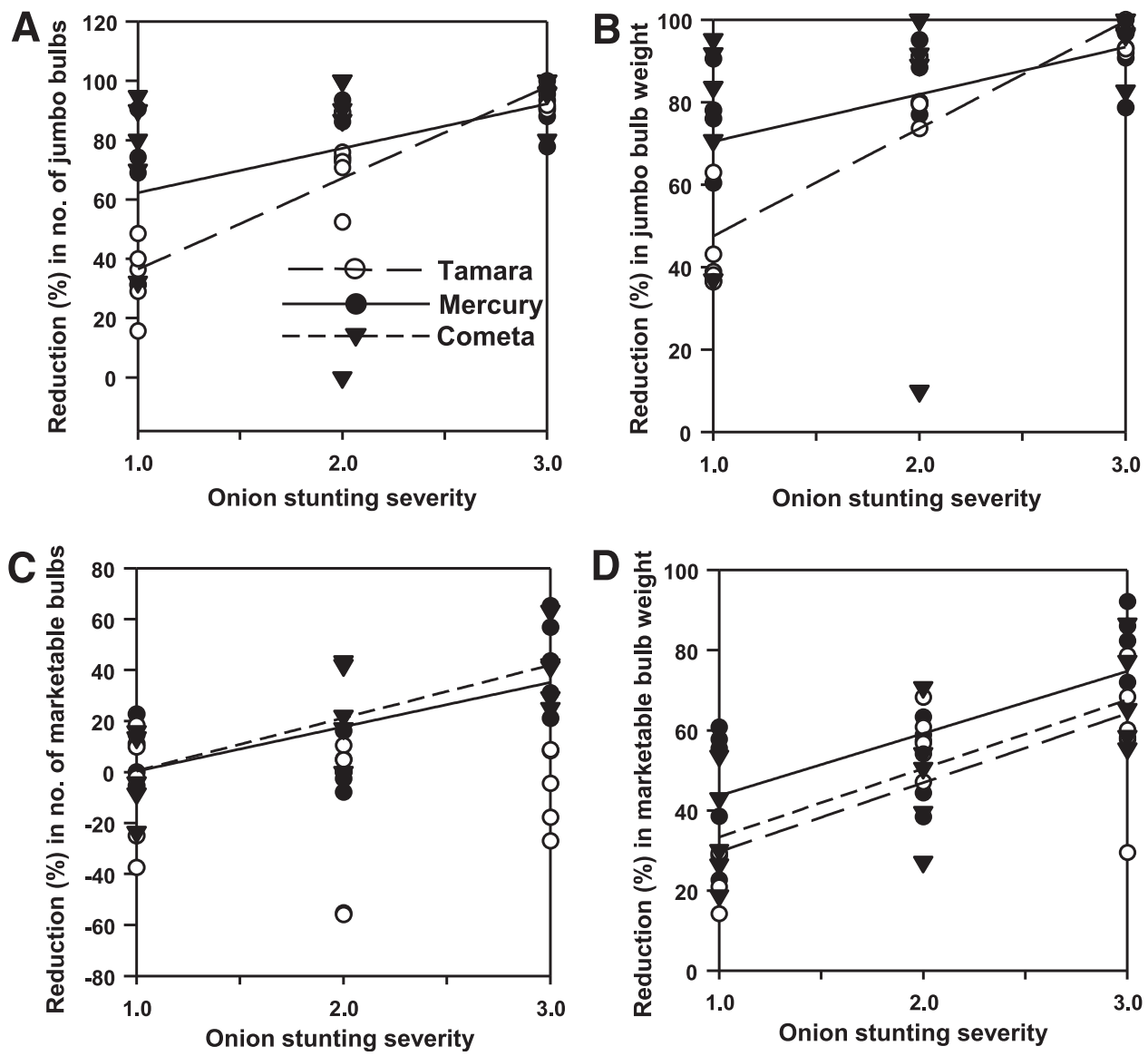

Fig. 5. Relationships between the percentage change in number or weight of onion bulbs of different size categories and severity of onion stunting (rated on a scale of 1 to 3 , as detailed in the main text) for each of three onion fields (cultivars) grown in the Columbia Basin of Oregon and Washington states in 2012. The cultivars Cometa, Mercury, and Tamara were planted in Fields C-R7, B-238, and A-R44, respectively. Regression equations were: (A) Cometa, NS (not significant at $P=0.05$ ); Mercury, $Y=47.8+14.9 x, R^{2}=$ $0.38, P=0.01$; and Tamara, $Y=5.69+30.7 x, R^{2}=0.86, P<0.0001$. (B) Cometa, NS; Mercury, $Y=59.4+11.5 x, R^{2}=0.36, P=0.01 ;$ and Tamara, $Y=21.4+26.1 x, R^{2}=0.86$, $P<0.0001$. (C) Cometa, $Y=-20.3+20.8 x, R^{2}=0.56, P=0.001$; Mercury, $Y=-17.8+17.5 x, R^{2}=0.41, P=0.007$; and Tamara, NS. (D) Cometa, $Y=16.2+17.1 x, R^{2}=0.54$, $P=0.002$; Mercury, $Y=27.8+15.5 x, R^{2}=0.48, P=0.003$; and Tamara, $Y=12.4+17.3 x, R^{2}=0.53, P=0.002$. 
$R$. oryzae (33). Therefore, the greater frequency of detection of $R$. ory$z a e$ in onion fields of the Columbia Basin than other Rhizoctonia species is not surprising. However, R. oryzae did not appear to play a primary role in causing onion stunting even though it was the most prevalent species detected from soil sampled within patches of stunted onion plants in this survey, and was detected less frequently from soil sampled outside the patches. This species was demonstrated to be a relatively weak pathogen of onion (30).

$R$. solani AG 3 was isolated primarily from soil samples compared with onion plants in this study. AG 3 is principally pathogenic on solanaceous crops $(5,14,30)$, so potato crops in the Columbia Basin may maintain AG 3 populations in fields in which onion crops are grown. Although AG 3 isolates did not cause severe onion stunting when evaluated in southern Australia (52), Patzek et al. (30) and Farrokhi-Nejad et al. (11) reported that isolates of AG 3 caused severe onion stunting in growth chamber trials. Isolates of AG 3 detected in this study were obtained primarily from inside patches of stunted onion plants ( 23 versus 6 isolates, respectively). Therefore, isolates of AG 3 may contribute to onion stunting in the Columbia Basin.

$R$. solani AG 4 was the second most frequent $R$. solani AG detected, and was isolated from soil inside and outside stunted patches, as well as from basal plates and roots of onion plants. Although AG 4 isolates have not been associated with onion stunting in cereal-onion cropping systems in the United States (30) or Australia (52), AG-4 isolates were reported to be pathogenic on onion in Turkey (9), New Zealand (11), and Israel (18). R. solani AG 4 has a wide host range $(1,6,14,50)$, and the prevalence of this AG detected in onion crops in the Columbia Basin in this study is most likely associated with the diversity of host crops rotated with onion in this region. $R$. solani AG-4 includes both pathogenic and nonpathogenic forms on various crops $(19,43)$, so it is possible onion plants may be infected asymptomatically or symptomatically by AG 4 isolates. Other pathogenicity tests of isolates of $R$. solani AG 4 from the Columbia Basin have demonstrated the isolates to be pathogenic (22)

In this study, 21 isolates of Ceratobasidium AG A (10\% of 251 isolates) were obtained from onion basal plates, and 4 from soil samples. AG A has not been reported as a pathogen of onion, but this AG includes both pathogenic and nonpathogenic isolates on other crops, with the former causing root rots and damping-off (43). Nonpathogenic isolates of AG A have been documented to form mycorrhizal associations with orchids (43).

$R$. solani AG 8 isolates made up $7 \%$ of the 251 isolates collected from onion fields in the Columbia Basin in this study. These isolates were obtained primarily from soil collected inside patches of stunted onion plants. Three isolates were from onion basal plates, and one from onion roots. The frequency of detection of AG 8 was less than expected given that AG 8 was the most pathogenic Rhizoctonia AG reported to cause onion stunting in cereal-onion cropping systems in southern Australia (52) and the Columbia Basin (30). AG 8 causes bare patch in wheat and barley in the Pacific Northwest (32,37), with root spear-tipping symptoms in these cereal crops that are similar to those observed on onion roots in stunted patches $(7,32)$. Although
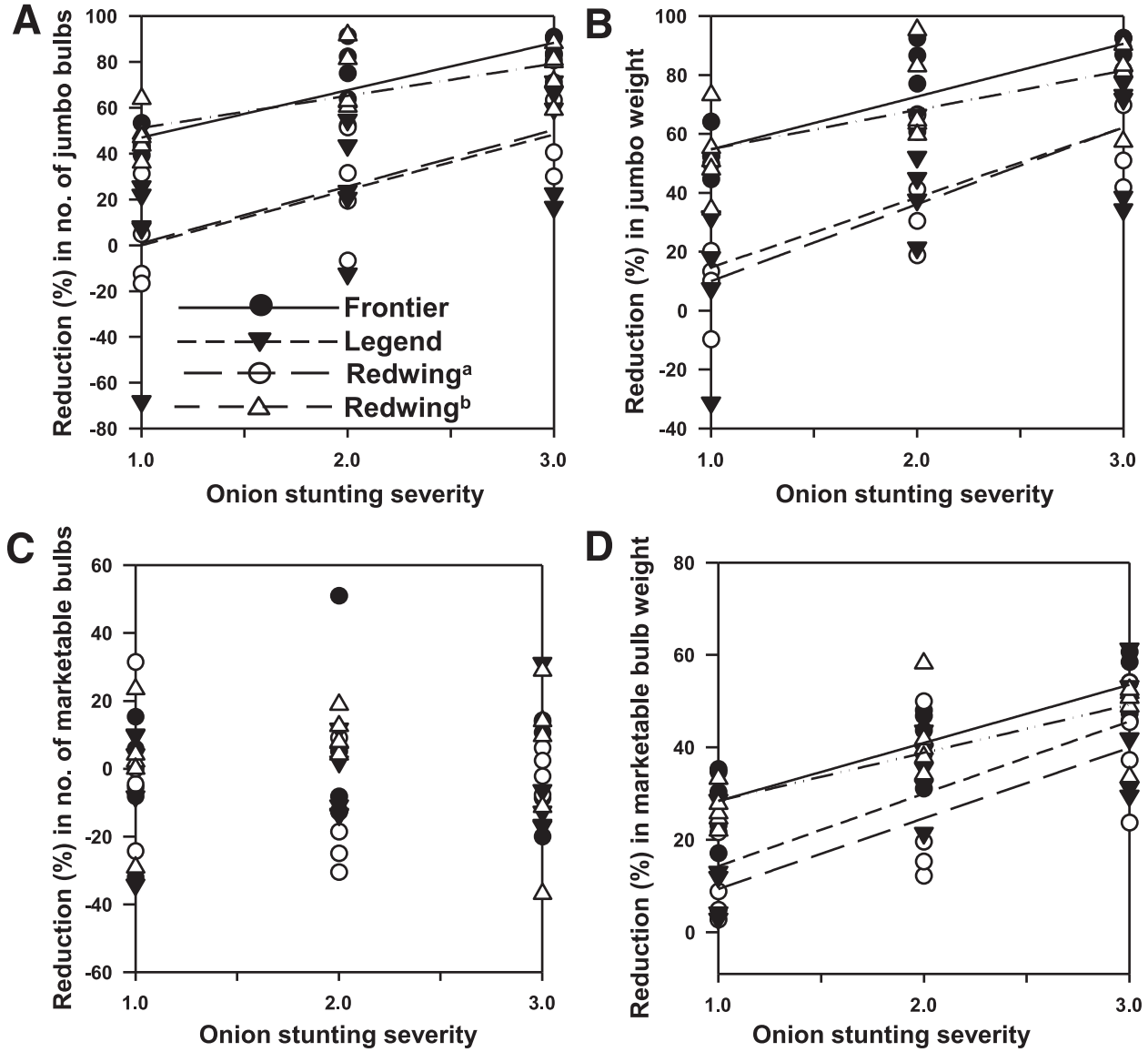

Fig. 6. Relationships between the percentage change in number or total weight of onion bulbs of different size categories and severity of onion stunting (rated on a scale of 1 to 3 , as detailed in the main text) for each of three onion fields (cultivars) grown in the Columbia Basin of Oregon and Washington states in 2013. The cultivars Frontier, Legend, and Redwing were planted in Fields B-240, B-774, and B-417 (Redwing ${ }^{\mathrm{a}}$ ) and A-756 (Redwing ${ }^{\mathrm{b}}$ ), respectively. Regression equations were: $(\mathbf{A})$ Frontier, $Y=26.4+20.7 \mathrm{x}$,

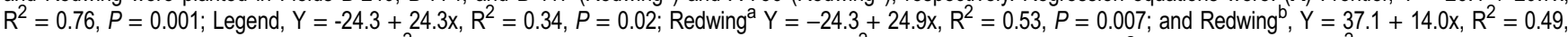
$P=0.003$. (B) Frontier, $Y=36.8+17.9 x, R^{2}=0.74, P=0.001$; Legend, $Y=-8.8+23.6 x, R^{2}=0.49, P=0.003 ; R^{2}$ dwing $^{a}, Y=-16.5+26.3 x, R^{2}=0.67, P=0.001 ;$ and Redwing ${ }^{b}, Y=41.4+13.4 x, R^{2}=0.41, P=0.009$. (C) NS regression equation for all four fields. (D) Frontier, $Y=15.8+12.6 x, R^{2}=0.72, P=0.001 ;$ Legend, $Y=-1.3+$ $15.6 x, R^{2}=0.60, P=0.0007$; Redwing ${ }^{a}, Y=-5.6+15.1 x, R^{2}=0.53, P=0.007$; and Redwing ${ }^{b}, Y=18.0+10.4 x, R^{2}=0.59, P=0.0009$. 
spear tip symptoms on onion plants sampled inside patches were common in this study, AG 8 isolates were not recovered at a great frequency from soil or onion plants. Jaaffar (20) reported a low frequency of AG 8 (6\% of 117 Rhizoctonia isolates) detected in cereal crops in the inland Pacific Northwest. Similarly, Patzek et al. (30) determined that AG 8 isolates comprised $16 \%$ of 45 isolates from onion fields in the Columbia Basin. R. solani AG 8 was detected in 24 of 36 soil samples (67\%) by real-time PCR assay in this study, and in only two soil samples $(6 \%)$ by toothpick baiting soil from a field experiment $(38,40)$. The toothpick baiting and real-time PCR assay did not detect isolates of AG 2-1 and AG 4, except for AG 2-1 detected in 1 of 36 soil samples by real-time PCR assay. The results suggest that, even when AG 8 is involved in diseases of various crops, this AG can be difficult to isolate from soil and/or plants $(16,31)$.

A relatively low incidence of $R$. solani AG 2-1 (6\% of 251 isolates) was detected in this study. AG 2-1 is cosmopolitan in wheat fields in the Pacific Northwest (20), and is detected readily in the Columbia Basin even in the absence of common crucifer hosts such as canola (Brassica napus L.) (14). Patzek et al. (30) isolated AG 2-1 from pea and onion plants in the Columbia Basin. The isolates were more pathogenic on onion than those of AG 4. In that study, AG 2-1 and AG E isolates also reduced onion emergence, unlike AG 8 isolates, which only affected plant height and weight. Wicks et al. (52) also observed a reduction in onion growth caused by isolates of AG 2-1 in Australia. However, the amount of AG 2-1 DNA detected did not correlate significantly with the degree of onion stunting in that study or this study. Therefore, AG 2-1 isolates may cause preemergence damping-off of onion rather than onion stunting.

Ceratobasidium AG K isolates comprised $6 \%$ of the 251 isolates in this survey. AG $\mathrm{K}$ isolates were reported as nonpathogenic on sugar beet (Beta vulgaris L. subsp. vulgaris), radish, tomato (Solanum lycopersicon Mill.), carrot, and onion seedlings $(43,47)$ but as a major root rot pathogen of strawberry (Fragaria $\times$ ananassa D.) in Western Australia (10). Also, AG K isolates from potato tubers in New Zealand were pathogenic on onion (11).

The Rhizoctonia AGs isolated from soil and plant samples may be influenced by incubation temperature during isolation. AG 8 isolates had slower growth rates than isolates of AG E, AG 3, and AG 4 when incubated on PDA at temperatures ranging from 10 to $30^{\circ} \mathrm{C}(30)$. Similarly, AG 2-1 isolates grew slower than AG 3 and AG 4 isolates at $18^{\circ} \mathrm{C}$ (21). Isolates of $R$. oryzae from the Pacific Northwest grew faster than AG 2-1 isolates, followed by AG 8 isolates, at 15 to $30^{\circ} \mathrm{C}$ (26). Therefore, incubating soil at $16^{\circ} \mathrm{C}$ for 2 days when baiting Rhizoctonia spp. using toothpicks (31), followed by incubation of the toothpicks (or onion basal plates or roots) at $24^{\circ} \mathrm{C}$, may have favored growth of isolates with higher temperature optima such as $R$. oryzae and $R$. solani AG 2-1, AG 3, and AG 4 compared with slower growing isolates such as $R$. solani AG 8.

The lack of association between soil DNA concentrations of $R$. solani AG 8 detected prior to planting (early March 2012) with any grower-perceived historical risk of onion stunting, or with severity of stunting observed in onion crops four months after sampling (May to June 2012), was not expected. Recommendations for farmers based on preplant DNA concentrations of soilborne pathogens, including $R$. solani AG 8, have been developed for cereal crops in southern Australia $(17,28,44)$, and more recently extended to onion crops (S. Anstis, personal communication). The SARDI recommendation for preplanting risk assessment is to collect about 45 soil cores from 15 locations per field using a "W" transect in each field $(28,44)$. In this study, soil samples were collected in early March 2012 from each of three transects per 50 ha field, with enough cores to comprise approximately $1 \mathrm{~kg}$ soil per transect. The low amount of AG 8 DNA detected might reflect inadequate sampling but may also reflect the extremely aggregated distribution of Rhizoctonia, which complicates collecting and testing samples to reflect the distribution of these soilborne pathogens. Also, the amount of $R$. solani AG 8 inoculum in soil increases rapidly but for a very limited duration ( 2 to 3 weeks) after cereal crops are sprayed with herbicide (3), complicating the ability to sample fields prior to killing the cereal cover crops with herbicide application, in order to predict the risk of onion stunting. Onion growers in the Columbia Basin indicated the need for a risk assessment tool that can be utilized the fall prior to planting winter cereal cover crops, to know which fields might be appropriate for a winter cereal cover crop preceding a spring-sown onion bulb crop (7).

The frequency and concentration of $R$. solani AG 8 DNA detected in soil by real-time PCR assay were greater inside patches of stunted onion plants than adjacent healthy areas of crops surveyed in 2012 at the five- to seven-true leaf stage of growth, but did not differ for AG 2-1, AG 3, and AG 4 DNA. However, the frequency and concentration of AG 8 (and AG 2-1, AG 3, and AG 4) DNA detected were not associated significantly with severity of stunting in 2013. In 2012, soil samples were collected in early June. In 2013, samples were collected in late June. Monthly mean temperatures in March, May, and June $2013\left(15,28\right.$, and $32^{\circ} \mathrm{C}$, respectively) were greater than in 2012 $\left(14,26\right.$, and $30^{\circ} \mathrm{C}$, respectively) in the Columbia Basin (http://prismmap. nacse.org/nn/), but the April mean temperature in $2012\left(21^{\circ} \mathrm{C}\right)$ was slightly greater than in $2013\left(20^{\circ} \mathrm{C}\right)$. Soil temperature and moisture influence activity of Rhizoctonia spp. $(12,42)$, e.g., a greater concentration of AG 8 DNA was detected in soil incubated at 15 versus $20^{\circ} \mathrm{C}(2)$. Warmer soil temperatures may influence microbial and nuclease activity, increasing the rate of decay of soil DNA (51). Therefore, spring temperature differences in 2012 versus 2013 may have resulted in less pathogen DNA detected with the real-time PCR assay in 2013 versus 2012. Detection of AG 8 DNA at a greater frequency ( $42 \%$ of 79 soil samples) by real-time PCR assay than with the toothpick baiting method (14\%) indicated greater sensitivity of the real-time PCR assay, which entailed DNA extraction from bulk soil samples of approximately $300 \mathrm{~g}$ versus only $100 \mathrm{~g}$ soil with the toothpick baiting method. Quantification of DNA using a real-time PCR assay with DNA extracted from bulk soil samples has been very sensitive for some pathogens $(28,53)$.

Six long-day onion cultivars, Cometa, Mercury, Tamara, Frontier, Legend, and Redwing, were assessed for yield loss caused by onion stunting in the Columbia Basin in this study. The results demonstrated variation in yield loss among these cultivars that are commonly grown in the Columbia Basin. Correlation analyses showed a reduction in total and marketable bulb weight with increasing severity of stunting. The number and weight of jumbo bulbs were inversely correlated with onion stunting severity for all cultivars except Cometa. For Cometa, the number and weight of medium bulbs were both inversely correlated with disease severity, reflecting the fact that the crop of Cometa surveyed had more medium bulbs than jumbo bulbs, even in healthy areas of the field. However, cultivar responses to onion stunting needs confirmation through experiments with side-by-side comparison of cultivars under the same production practices and environmental conditions because cultivars were confounded with farms and years in this study. Quantifying the performance of onion cultivars under field conditions in the presence of onion stunting is important to assess the potential economic impact of the disease. Reduction in marketable bulb weight was equal to or greater than the reduction in total bulb weight for all cultivars except Frontier. In the field of Frontier, culled bulbs were absent or present at a low incidence within stunted patches compared with adjacent areas. Therefore, total yield loss was greater than marketable yield loss. For the cultivar Redwing evaluated in two fields, onion stunting significantly reduced the weight of total bulbs and marketable bulbs. Reduction in marketable bulb weight was 27, 42, and $47 \%$ in Field A-756; and 10, 24, and 40\% in Field B-417 in patches with stunting severity ratings of 1,2 , and 3 , respectively. Variation in yield loss for the same cultivar in different fields may have been associated with differences in cultural practices, environment, disease pressure, and pathogen population between fields $(36,54)$. Patches with the three severity ratings of stunting were selected in each field. However, variation in severity of stunting occurred among plants within each patch, which may have contributed to variation in yield loss estimated among patches and/or fields, even for the same cultivar.

Correlation and regression models showed consistent results for reduction in number and weight of jumbo bulbs, and reduction in weight of total bulbs and marketable bulbs for most of the cultivars/fields evaluated in this study. There was no significant 
correlation between onion stunting severity and number of total bulbs or number of marketable bulbs for five of the seven fields, or when averaged across all fields evaluated/year or all seven fields. This supported previous evidence that onion stunting does not reduce the stand of onion plants, but that reduction in onion yield in stunted patches is due to reduction in size of the bulbs. A mean reduction in bulb size of $28 \%$ in stunted patches compared with healthy areas was reported in southern Australia (2). Larger onion bulbs have greater market value than smaller onions for most markets of onions grown in the Columbia Basin (T. Waters, Washington State University Regional Extension Specialist, personal communication). Therefore, onion stunting not only reduces marketable bulb number and weight for growers, but also the market value of crops. For two of the cultivars evaluated in this study, Cometa and Mercury, there was a significant reduction in numbers of total and marketable bulbs. Isolates of $R$. solani AG 2-1 and AG 3 might have reduced plant stands in these fields by causing pre-emergence damping-off (30). However, the absence or rare presence of AG 2-1 and AG 3 isolates revealed by toothpick baiting and real-time PCR assays for soil sampled from stunted patches suggests isolates of these two AGs probably did not affect yield in these fields.

The assessment of yield losses caused by onion stunting in this study was completed in seven commercial onion fields. Although the yield losses likely were influenced by cultivation and other practices on individual farms, in addition to biotic and abiotic heterogeneity within fields, the primary relationships between disease severity and yield parameters were relatively consistent among cultivars and years. Correlation coefficients ranged from 0.54 to 0.93 for severity of onion stunting and onion yield loss parameters. Estimation of linear regression relationships for different onion bulb sizes among the six cultivars may enable estimation of the economic impact of onion stunting in the Columbia Basin. This could be utilized along with aerial infrared images of onion fields that growers in this region routinely take of their crops, to estimate the cumulative area of stunted patches in fields and, thereby, to calculate yield loss for individual fields. Similarly, these regression equations could be used to calculate gains in bulb yield and cost-benefit analyses of management practices for onion stunting, e.g., the timing of herbicide application to cereal cover crops $(38,40)$, or broadcast and incorporated application of fungicides such as azoxystrobin prior to planting onion crops (41).

\section{Acknowledgments}

This research was supported by the Washington State Department of Agriculture Specialty Crop Block Grant Program (Grant Agreement No. K525); CRIS Project WPN05595; and Washington State University (WSU) College of Agricultural, Human, \& Natural Resource Sciences, WSU Agricultural Research Center, and WSU Department of Plant Pathology (PPNS number 0652). We thank M. Handiseni for collection of Rhizoctonia spp. isolates in 2010; K. Schroeder and A. Prescott for technical assistance in the lab; E. Thomas, J. Eggers, and S. Kandel for assistance in the fields; and Drs. David M. Weller and Dennis A. Johnson for reviewing the manuscript. We are thankful to onion grower-cooperators in the Columbia Basin who allowed us to survey their onion fields.

\section{Literature Cited}

1. Anderson, N. A. 1982. The genetics and pathology of Rhizoctonia solani. Annu. Rev. Phytopathol. 20:329-347.

2. Anstis, S. T., Wicks, T. J., and Pederick, S. 2012. Rhizoctonia solani AG-8 associated with stunted onion patches in South Australia. Acta Hortic. 969: 247-253.

3. Babiker, E. M., Hulbert, S. H., Schroeder, K. L., and Paulitz, T. C. 2011. Optimum timing of preplant applications of glyphosate to manage Rhizoctonia root rot in barley. Plant Dis. 95:304-310.

4. Carling, D. E. 1996. Grouping of Rhizoctonia solani by hyphal anastomosis reactions. Pages 37-47 in: Rhizoctonia Species: Taxonomy, Molecular Biology, Ecology, Pathology and Disease Control. Kluwer Academic Publishers, Dordrecht, The Netherlands.

5. Carling, D. E., and Leiner, R. H. 1990. Virulence of isolates of Rhizoctonia solani AG-3 collected from potato plant organs and soil. Plant Dis. 74: 901-903.

6. Carling, D. E., and Summer, D. R. 1992. Rhizoctonia. Pages 157-165 in: Methods for Research on Soilborne Phytopathogenic Fungi. L. L. Singleton, J. D. Mihail, and C. M. Rush, eds. The American Phytopathological Society, St Paul, MN.
7. du Toit, L. J. 2009. Rhizoctonia seedling blight of onion in the Columbia Basin. 2009 Washington State University Onion Field Day, Quincy, WA.

8. du Toit, L. J., Poudyal, D. S., Paulitz, T., Porter, L., Eggers, J., and Hamm, P. 2012. Onion stunting caused by Rhizoctonia: Management and economic importance in the Columbia Basin of Oregon and Washington. Pages 68-77 in: Proc. 2012 Nat. Allium Res. Conf., Las Cruces, NM. http://aces.nmsu. edu/narc2012/index.html

9. Erper, I., Karaca, G. H., Turkkan, M., and Ozkoc, I. 2006. Characterization and pathogenicity of Rhizoctonia spp. from onion in Amasya, Turkey. Phytopathology 154:75-79.

10. Fang, X., Finnegan, P. M., and Barbetti, M. J. 2013. Wide variation in virulence and genetic diversity of binucleate Rhizoctonia isolates associated with root rot of strawberry in Western Australia. PLoS ONE 8:e55877.

11. Farrokhi-Nejad, R., Cromey, M. G., and Moosawi-Jorf, S. A. 2007. Determination of the anastomosis grouping and virulence of Rhizoctonia spp. associated with potato tubers grown in Lincoln, New Zealand. Pak. J. Biol. Sci. 10:3786-3793.

12. Gill, J. S., Sivasithamparam, K., and Smettem, K. R. J. 2001. Soil moisture affects disease severity and colonisation of wheat roots by Rhizoctonia solani AG-8. Soil Biol. Biochem. 33:1363-1370.

13. Goll, M. B., Schade-Schütze, A., Swart, G., Oostendorp, M., Schott, J. J., Jaser, B., and Felsenstein, F. G. 2014. Survey on the prevalence of Rhizoctonia spp. in European soils and determination of the baseline sensitivity towards sedaxane. Plant Pathol. 63:148-154.

14. Gonzalez Garcia, V., Onco, M. A. P., and Susan, V. R. 2006. Biology and systematics of the form genus Rhizoctonia. Span. J. Agric. Res. 4:55-79.

15. Gunnell, P. S. 1986. Characteristics of the teleomorphs of Rhizoctonia oryzaesativae, Rhizoctonia oryzae, and Rhizoctonia zeae, and the effect of cultural practices on aggregate sheath spot of rice, caused by $R$. oryzae-sativae Ph.D. Dissertation. University California, Davis, CA.

16. Harris, J. R., and Moen, R. 1985. Replacement of Rhizoctonia solani on wheat seedlings by a succession of root-rot fungi. Trans. Br. Mycol. Soc. 84:11-20

17. Herdina, R. D. K., Coppi, J. A., and Gupta, V. V. S. R. 2001. Investigation of the mechanisms of disease suppression in soil using DNA techniques. Page 88 in: Proc. Second Australasian Soilborne Diseases Symp. I. Porter, D. deBoer, D. Cahill, J. Edwards, G. Hollaway, J. Irwin, R. Falloon, K. Ophel-Keller, R. Magarey, and I. Smith, eds. Department of Natural Resources and Environment, Melbourne.

18. Ichielevich-Auster, M., Sneh, B., Koltin, Y., and Barash, I. 1985 Pathogenicity, host specificity and anastomosis groups of Rhizoctonia spp. isolated from soils in Israel. Phytoparasitica 13:103-112.

19. Ichielevich-Auster, M., Sneh, B., Barash, I., and Koltin, Y. 1985. Suppression of damping-off caused by Rhizoctonia spp. by a nonpathogenic isolate of $R$. solani. Phytopathology 75:1080-1084.

20. Jaaffar, A. K. M. 2012. Isolation, identification, pathogenicity and sensitivity of Rhizoctonia spp. to phenazine-1-carboxylic acid (PCA)-producing Pseudomonas spp. Ph.D. Dissertation, Washington State University, Pullman, WA.

21. Kaminski, D. A., and Verma, P. R. 1985. Cultural characteristics, virulence, and in vitro temperature effect on mycelial growth of Rhizoctonia isolates from rapeseed. Can. J. Plant Pathol. 7:256-261.

22. Langston, D. B., and Seebold, K. W. 2008. Rhizoctonia seed rot and seedling diseases. Pages 10-11. in: Compendium of Onion and Garlic Diseases and Pests, 2nd Ed., H. F. Schwartz, and S. K. Mohan, eds. The American Phytopathological Society, St. Paul, MN.

23. Larkin, R. P., and Honeycutt, C. W. 2006. Effects of different 3-year cropping systems on soil microbial communities and Rhizoctonia diseases of potato. Phytopathology 96:68-79.

24. MacNish, G. C., and Neate, S. M. 1996. Rhizoctonia bare patch of cereals, An Australian perspective. Plant Dis. 80:965-971.

25. Ogoshi, A. 1987. Ecology and pathogenicity of anastomosis and intraspecific groups of Rhizoctonia solani Kühn. Annu. Rev. Phytopathol. 25:125-143.

26. Ogoshi, A., Cook, R. J., and Bassett, E. N. 1990. Rhizoctonia species and anastomosis groups causing root rot of wheat and barley in the Pacific Northwest. Phytopathology 80:784-788.

27. Ohkura, M., Abawi, G. S., Smart, C. D., and Hodge, K. T. 2009. Diversity and aggressiveness of Rhizoctonia solani and Rhizoctonia-like fungi on vegetables in New York. Plant Dis. 93:615-624.

28. Ophel-Keller, K., Mackay, A., Hartley, H., and Curran, J. 2008. Development of a routine DNA-based testing service for soilborne diseases in Australia Australas. Plant Pathol. 37:243-253.

29. Parmeter, J. R., Jr., and Whitney, H. S. 1970. Taxonomy and nomenclature of the imperfect state. Pages 7-19 in: Rhizoctonia solani: Biology and Pathology. University of California Press, Berkeley, CA

30. Patzek, L. J., du Toit, L. J., Paulitz, T. C., and Jones, S. S. 2013. Stunting of onion in the Columbia Basin of Oregon and Washington caused by Rhizoctonia spp. Plant Dis. 97:1626-1635.

31. Paulitz, T. C., and Schroeder, K. L. 2005. A new method for the quantification of Rhizoctonia solani and R. oryzae from soil. Plant Dis. 89:767-772.

32. Paulitz, T. C., Schroeder, K. L., and Schillinger, W. F. 2010. Soilborne pathogens of cereals in an irrigated cropping system: effects of tillage, residue management, and crop rotation. Plant Dis. 94:61-68.

33. Paulitz, T. C., Smith, J. D., and Kidwell, K. K. 2003. Virulence of Rhizoctonia oryzae on wheat and barley cultivars from the Pacific Northwest. Plant Dis. 87:51-55. 
34. Paulitz, T. C., Zhang, H., and Cook, R. J. 2001. Spatial distribution of Rhizoctonia root rot in direct-seeded barley. Phytopathology 91:S70 (Abstr.).

35. Pelter, G. Q., and Sorensen, E. J. 2003. Crop profile for onions in Washington. Regional Integrated Pest Management Centers, United States Department of Agriculture.

36. Savary, S., Teng, P. S., Willocquet, L., and Nutter, F. W., Jr. 2006. Quantification and modeling of crop losses: a review of purposes. Annu. Rev. Phytopathol. 44:89-112.

37. Schillinger, W. F., and Paulitz, T. C. 2006. Reduction of Rhizoctonia bare patch in wheat with barley rotations. Plant Dis. 90:302-306.

38. Sharma-Poudyal, D., Paulitz, T., Porter, L., Eggers, J., Hamm, P., and du Toit, L. J. 2013. Effect of timing of glyphosate application to a winter cover crop on stunting of spring-sown onions caused by Rhizoctonia spp. in the Columbia Basin of Washington, 2012. Plant Dis. Manage. Rep. 7:V046.

39. Sharma-Poudyal, D., Paulitz, T., Porter, L., Eggers, J., Hamm, P., and du Toit, L. J. 2013. Yield responses of three onion cultivars to stunting caused by Rhizoctonia spp. in the Columbia Basin of Oregon and Washington, 2012. Plant Dis. Manage. Rep. 7:V048.

40. Sharma-Poudyal, D., Paulitz, T., Porter, L., Eggers, J., Hamm, P., and du Toit, L. J. 2013. Rhizoctonia spp. dynamics and optimal timing of glyphosate application to cereal cover crops to manage onion stunting in Washington and Oregon. Phytopathology 103:S221-O (Abstr.).

41. Sharma-Poudyal, D., Paulitz, T., Porter, L., Eggers, J., Hamm, P., and du Toit, L. J. 2013. Efficacy of fungicides to manage onion stunting caused by Rhizoctonia spp. in the Columbia Basin of Oregon and Washington, 20112012. Plant Dis. Manage. Rep. 7:V047.

42. Smiley, R. W., and Uddin, W. 1993. Influence of soil temperature on Rhizoctonia root rot ( $R$. solani AG-8 and $R$. oryzae) of winter wheat. Phytopathology 83:777-785.

43. Sneh, B., Burpee, L., and Ogoshi, A. 1991. Identification of Rhizoctonia species. American Phytopathological Society Press, St. Paul, MN.
44. South Australian Research and Development Institute. 2014. PreDicta B.<http:// www.sardi.sa.gov.au/products_and_services/entomology/diagnostic_service/ predicta_b>, Urrbrae, Australia (downloaded 28 Jan. 2014).

45. Stodart, B. J., Harvey, P. R., Neate, S. M., Melanson, D. L., and Scott, E. S. 2007. Genetic variation and pathogenicity of anastomosis group 2 isolates of Rhizoctonia solani in Australia. Mycol. Res. 111:891-900.

46. Tewoldemedhin, Y. T., Lamprecht, S. C., McLeod, A., and Mazzola, M. 2006. Characterization of Rhizoctonia spp. recovered from crop plants used in rotational cropping systems in the Western Cape Province of South Africa. Plant Dis. 90:1399-1406.

47. Tuncer, S., and Eken, C. 2013. Anastomosis grouping of Rhizoctonia solani and binucleate Rhizoctonia spp. isolated from pepper in Erzincan, Turkey. Plant Prot. Sci. 49:127-131.

48. Tupac Otero, J., Ackerman, J. D., and Bayman, P. 2002. Diversity and host specificity of endophytic Rhizoctonia-like fungi from tropical orchids. Am J. Bot. 89:1852-1858.

49. United States Department of Agriculture National Agricultural Statistics Service. Vegetables 2011 summary. Tech. Rep. January 2012.

50. Vincelli, P. C., and Herr, J. J. 1992. Two diseases of alfalfa caused by Rhizoctonia solani AG-1 and AG-4. Plant Dis. 76:1283.

51. Wackernagel, W. 2006. The various sources and the fate of nucleic acids in soil. Pages 117-139. in: Nucleic Acids and Proteins in Soil. P. Nannipieri and K. Smalla, eds. Springer, Berlin.

52. Wicks, T., Walker, G., Pederick, S., and Anstis, S. 2011. Onion stunting in South Australia associated with Rhizoctonia solani AG 8. Australas. Plant Pathol. 40:126-132.

53. Woodhall, J. W., Adams, I. P., Peters, J. C., Harper, G., and Boonham, N. 2013. A new quantitative real-time PCR assay for Rhizoctonia solani AG3-PT and the detection of AGs of Rhizoctonia solani associated with potato in soil and tuber samples in Great Britain. Eur. J. Plant Pathol. 136:273-280.

54. Yang, X. B., Lundeen, P., and Uphoff, M. D. 1999. Soybean varietal response and yield loss caused by Sclerotinia sclerotiorum. Plant Dis. 83:456-461. 